\title{
FREQUENCY OF THREE HEMOCHROMATOSIS GENE MUTATIONS IN ANTALYA, TURKEY
}

\author{
Oztürk S, Lüleci G, Keser I*
}

*Corresponding Author: Associate Professor Dr. Ibrahim Keser, Department of Medical Genetics, School of Medicine, Akdeniz University, 07070 Antalya, Turkey; Tel.: +90-242-249-6000, Ext: 6973; Fax: +90-242-227-4484; Mobile Tel.:+90-532-788-7644; E-mail: keser@akdeniz.edu.tr

\begin{abstract}
Hemochromatosis gene (HFE) mutations are associated with hereditary hemochromatosis. We used the polymerase chain reaction-restriction fragment length polymorphism (PCR-RFLP) method to determine the frequency of the mutations (C282Y, S65C and H63D) of the HFE gene in DNA samples of 141 healthy Turkish adults in Antalya, Turkey. The mutant allele frequencies were 0.0, 0.0 and 0.12 , respectively. The H63D mutation was found in the heterozygous state in 30 samples $(21.27 \%)$ and in the homozygous state in two samples (1.41\%). These results suggest that the H63D mutation may be responsible for the hereditary hemochromatosis in the Turkish population.
\end{abstract}

Key words: Hereditary hemochromatosis, Hemochromatosis gene (HFE), C282Y, S65C, H63D, Antalya.

\section{INTRODUCTION}

Hereditary hemochromatosis is an autosomal recessive disorder of iron regulation that results in excessive intestinal absorption of iron. This metabolism leads to early multi systemic and non specific signs such as liver cirrhosis, hepatocellular carcinoma, diabetes mellitus, skin pigmentation, hypogonadotrophic hypogonadism, arthropathy

\footnotetext{
* Department of Medical Genetics, School of Medicine, Akdeniz University, 07070 Antalya, Turkey
}

and cardiomyopathy [1]. The hemochromatosis gene (HFE) is localized in human chromosome 6 21.3 [2]. Homozygosity for the C282Y mutation has been reported in $60-100 \%$ of individuals with hemochromatosis in European populations [3]. However, the H63D mutation has a frequency of approximately $16 \%$ in the European populations $[2,3]$. The S65C mutation is much rarer and is associated with a mild form of hemochromatosis [4]. In the general population in Europe, the prevalence of the $\mathrm{C} 282 \mathrm{Y}$ mutation is estimated to be $9.2 \%$ (heterozygote) and $0.4 \%$ (homozygote). The prevalence of the $\mathrm{C} 282 \mathrm{Y}$ mutation differs in different populations in the Slavic populations (1.9\% in the former USSR and $10.0 \%$ in the Czech Republic). This mutation is absent in populations outside Europe and the USA [5].

The prevalence of the $\mathrm{S} 65 \mathrm{C}$ mutation that has been associated with the development of a mild form of iron overload is 5.0\% in the Republic of Macedonia [6], 2.5\% in France [4], 1.5\% in Denmark [7] and $1.1 \%$ in the USA [5]. The prevalence of the H63D mutation is equally high in northwestern and southern European populations, where $22.0 \%$ are estimated to be heterozygotes and $2.0 \%$ homozygotes. It is the highest in Spain (32.1\%), lower in Norway and the former USSR (18.0\%) and in India (15.0\%). It is very rare outside Europe and the USA [5].

The aim of this study was to determine the frequency of HFE gene mutations (C282Y, S65C, and H63D) in Antalya, Turkey, which is a bridge between Asia and Europe. 


\section{MATERIALS AND METHODS}

A total of 141 random DNA samples from healthy adult volunteers ( 92 females, 49 males, age ranges from 20 to 61) who reside in Antalya, Turkey, were genotyped for HFE mutations (C282Y, S65C, and H63D). Written consent was obtained from each individual enrolled in this research.

Genomic DNA was isolated from peripheral blood leukocytes by a salting-out method [8]. The mutations were detected by a polymerase chain reaction-restriction fragment length polymorphism (PCR-RFLP) method [2]. The PCR was carried out in a Thermal Cycler (Techne-Genius, Cambridge, Cambridgeshire, UK). Each exon was amplified using the primers designed by Feder et al. [2]. The amplified fragments were $208 \mathrm{bp}$ for H63D and S65C and 390 bp for $\mathrm{C} 282 \mathrm{Y}$. The PCR products were digested with the restriction enzymes RsaI for C282Y, Hinfl for S65C and MboI for H63D. The restriction fragments were visualized after electrophoresis on a 3\% agarose gel stained with ethidium bromide. Quality control of the enzyme digestions was confirmed by positive and negative control DNAs.

\section{RESULTS}

The allelic frequencies and genotypes of the mutations found are summarized in Table 1. The H63D mutation was found in the heterozygous state in 30 individuals (21.28\%), and in the homozygous state in two individuals $(1.42 \%)$. The frequencies of the $\mathrm{H}$ and $\mathrm{D}$ alleles of the H63D mutation were found to be 0.88 and $0.12 \%$, respectively. These results are in keeping with other reports from different population studies (Table 2).

Table 1. Distribution of allelic frequencies of the HFE gene mutations in healthy Turkish individuals

\begin{tabular}{|c|c|c|c|c|c|}
\hline HFE Mutations & Alleles Studied & \multicolumn{3}{|c|}{ Number of Individuals } & Mutant Allele Frequency \\
\hline & & WT/WT & WT/Mut & Mut/Mut & \\
\hline $\mathrm{C} 282 \mathrm{Y}$ & 282 & 141 & 0 & 0 & 0.0 \\
\hline S65C & 282 & 141 & 0 & 0 & 0.0 \\
\hline H63D & 282 & 109 & 30 & 2 & 0.12 \\
\hline
\end{tabular}

WT: wild type, Mut: mutated type.

Table 2. Frequencies (\%) of the HFE mutations C282Y, H63D and S65C in different populations

\begin{tabular}{|l|l|r|r|r|}
\hline \multicolumn{2}{|c|}{ Population } & Reference(s) & \multicolumn{3}{|c|}{ C828Y } & S65C & H63D \\
\hline Europe: & & & & \\
- Spain & $9 ; 10$ & 3.0 & 0.0 & 21.7 \\
- France & $4 ; 5$ & 4.2 & 2.5 & 15.8 \\
- Italy & $5 ; 11$ & 1.1 & 1.3 & 11.9 \\
- Denmark & $1 ; 13$ & 5.7 & 1.5 & 13.3 \\
- Sweden & $5 ; 13$ & 3.9 & 1.6 & 12.5 \\
- Norway & 5 & 6.4 & $0.0^{\mathrm{a}}$ & 11.2 \\
- Faroe Islands & 1 & 6.6 & 1.0 & 15.3 \\
- Macedonia & 6 & 1.0 & 5.0 & 21.0 \\
\hline The Americas: & & & & \\
- Connecticut, USA & 5 & 5.0 & $0.0^{\mathrm{a}}$ & 16.0 \\
- Missouri, USA & 5 & 4.9 & $0.0^{\mathrm{a}}$ & 15.4 \\
- Alabama, USA & 5 & 6.0 & $0.0^{\mathrm{a}}$ & 12.7 \\
- Brazil & 14 & 0.0 & $0.0^{\mathrm{a}}$ & 0.0 \\
- Ecuador & 15 & 0.0 & 4.0 & 3.5 \\
\hline Asia: & & & & \\
- China & 5 & 0.0 & 2.8 & $0.0^{\mathrm{a}}$ \\
- Japan & 16 & 0.0 & 1.5 & $0.0^{\mathrm{a}}$ \\
- Turkey & Present study & 0.0 & 12.0 & 0.0 \\
\hline
\end{tabular}

${ }^{\text {a }}$ These mutations were not tested for in their studies. 


\section{DISCUSSION}

Hereditary hemochromatosis is the most prevalent monogenic disease in Caucasian European populations. It has been reported that the frequency of the $\mathrm{C} 282 \mathrm{Y}$ mutation is high in people of Anglo-Celtic origin $[2,5,12,17]$. Heterozygotes are very common in Ireland (28.4\%) [5], Denmark (13.7\%) [12], Norway $(12.8 \%)$ [5] and Iceland (10.0\%), and less common in southern Europe: Greece (2.6\%), Italy $(2.2 \%)$ and Spain (4.5\%) [5]. This mutation is less frequent in people from southern Europe and present at very low frequencies or absent in the Asiatic and African populations [5,20,21]. We did not find the $\mathrm{C} 282 \mathrm{Y}$ and $\mathrm{S} 65 \mathrm{C}$ mutations in Antalya, Turkey. This result is similar to those published for the Brazilian [14], Chinese [5] and Japanese [16] populations, excluding $4.0 \%$ for the frequency of the $\mathrm{S} 65 \mathrm{C}$ mutation in the Ecuadorian population [15]. In addition, Bozkaya et al. [22], Merryweather-Clarke et al. [23], Simsek et al. [24] and Barut et al. [25], did not observe the $\mathrm{C} 282 \mathrm{Y}$ mutation, and also did not test for the S65C mutation in their Turkish population. Prevalence of the H63D mutation was high in the present study, such as in the Macedonian population [6]. Therefore, we believe that our data are important due to being a bridge between Asia and Europe. Full phenotypic expression of hereditary hemochromatosis is very rare in the population of Antalya. However, the H63D mutation may be responsible for the hereditary hemochromatosis in the Turkish population.

\section{ACKNOWLEDGMENTS}

This study was supported by the Scientific Research Management Unit of Akdeniz University, Antalya, Turkey, and was approved by the local Ethics Committee.

\section{REFERENCES}

1. Milman N, Steig T, Koefoed P, Pedersen $\mathrm{P}$, Fenger K, Nielsen FC. Frequency of the hemochromatosis HFE mutations C282Y, H63D, and $\mathrm{S} 65 \mathrm{C}$ in blood donors in the Faroe Islands. Ann Hematol 2005; 84(3): 146-149.

2. Feder JN, Gnirke A, Thomas W, Tsuchihashi Z, Ruddy DA, Basava A, Dormishian F, Domingo R Jr, Ellis MC, Fullan A, Hinton LM, Jones NL,
Kimmel BE, Kronmal GS, Lauer P, Lee VK, Loeb DB, Mapa FA, McClelland E, Meyer NC, Mintier GA, Moeller N, Moore T, Morikang E, Prass CE, Quintana L, Starnes SM, Schatzman RC, Brunke KJ, Drayna DT, Risch NJ, Bacon BR, Wolff RK. A novel MHC class I-like gene is mutated in patients with hereditary haemochromatosis. Nat Genet 1996; 13(4): 399-408.

3.LyonE,FrankLE.Hereditaryhemochromatosis since discovery of the HFE gene. Clin Chem 2001; 47(7): 1147-1156.

4. Mura C, Férec C. HFE mutations analysis in 711 hemochromatosis probands: evidence for S65C implication in mild form of hemochromatosis. Blood 1999; 93(8): 2502-2505.

5. Hanson EH, Imperatore G, Burke W. HFE gene and hereditary hemochromatosis: aHuGe review. Am J Epidemiol 2001; 154(3): 193-206.

6. Arsov T, Petlichkoviski A, Strezova A, JurharPavlova M, Trajkov D, Spiroski M. Prevalence of the hereditary hemochromatosis mutations $(\mathrm{C} 282 \mathrm{Y}$, H63D and S65C) in the Republic of Macedonia. BJMG 2002; 5(1\&2): 11-14.

7. Simonsen K, Dissing J, Rudbeck L, Schwartz M. Rapid and simple determination of hereditary haemochromatosis mutations by multiplex PCRSSCP: detection of a new polymorphic mutation. Ann Hum Genet 1999; 63(3): 193-197.

8. Miller SA, Dykes DD, Polesky HF. A simple salting-out procedure for extracting DNA from human nucleated cells. Nucleic Acids Res 1988; 16(3): 1215.

9. Sanchez M, Bruguera M, Bosch J, Rodes J, Ballesta F, Oliva R. Prevalence of the Cys282Tyr and His63Asp HFE gene mutations in Spanish patients with hereditary hemochromatosis and in controls. J Hepatol 1998; 29(5): 725-728.

10. Remacha AF, Barcelo MJ, Sarda MP, Blesa I, Altes A, Baiget M. The S65C mutation in Spain. Implications for iron overload screening. Haematologica 2000; 85(12): 1324-1325.

11. Mariani R, Salvioni A, Corengia C, Erba N, Lanzafame C, De Micheli V, Baldini V, Arosio C, Fossati L, Trombini P, Oberkanins C, Piperno A. Prevalence of HFE mutations in upper Northern Italy: study of 1132 unrelated blood donors. Dig Liver Dis 2003; 35(7): 479-481.

12. Milman N, Pedersen P, Ovesen L, Melsen $\mathrm{GV}$, Fenger K. Frequency of the C282Y and H63D mutations of the hemochromatosis gene (HFE) in 
2501 ethnic Danes. Ann Hematol 2004; 83(10): 654-657.

13. Holmstrom P, Marmur J, Eggertsen G, Gafvels M, Stal P. Mild iron overload in patients carrying the HFE S65C gene mutation: a retrospective study in patients with suspected iron overload and healthy controls. Gut 2002; 51(5): 723-730.

14. Agostinho MF, Arruda VR, Basseres DS, Bordin S, Soares MC, Menezes RC, Costa FF, Saad ST. Mutation analysis of the HFE gene in Brazilian populations. Blood Cells Mol Dis 1999; 25(5\&6): 324-327.

15. Leone PE, Gimenez P, Collantes JC, Paz-yMino C. Analysis of HFE gene mutations (C282Y, $\mathrm{H} 63 \mathrm{D}$, and $\mathrm{S} 65 \mathrm{C}$ ) in the Ecuadorian population. Ann Hematol 2005; 84(2): 103-105.

16. Sohda T, Takeyama Y, Irie M, Kamimura S, Shijo H. Putative hemochromatosis gene mutations and alcoholic liver disease with iron overload in Japan. Alcohol Clin Exp Res 1999; 23(4): 21S-23S.

17. Olynyk JK. Hereditary haemochromatosis: diagnosis and management in the gene era. Liver 1999; 19(2): 73-80.

18. Barton JC, Bertoli LF. Haemochromatosis: the genetic disorder of the twenty-first century. Nat Med 1996; 2(4): 394-395.

19. Burke W, Thomson E, Khoury MJ, McDonnell SM, Press N, Adams PC, Barton JC, Beutler E, Brittenham G, Buchanan A, Clayton EW, Cogswell ME, Meslin EM, Motulsky AG, Powell LW, Sigal E, Wilfond BS, Collins FS.
Hereditary hemochromatosis: gene discovery and its implications for population-based screening. JAMA 1998; 280(2): 172-178.

20. Chang JG, Liu TC, Lin SF. Rapid diagnosis of the HLA-H gene Cys 282 Tyr mutation in hemochromatosis by polymerase chain reaction - a very rare mutation in the Chinese population. Blood 1997; 89(9): 3492-3493.

21. Monaghan KG, Rybicki BA, Shurafa M, Feldman GL. Mutation analysis of the HFE gene associated with hereditary hemochromatosis in African Americans. Am J Hematol 1998; 58(3): 213-217.

22. Bozkaya H, Bektas M, Metin O, Erkan O, Ibrahimoglu D, Dalva K, Akbiyık F, Gurel S, Bozday1 AM, Akay C, Yurdaydın C, Aslan O, Uzunalimoğlu O. Screening for hemochromatosis in Turkey. Diges Dis Sci 2004; 49(3): 444-449.

23. Merryweather-Clarke AT, Pointon JJ, Shearman JD. Global prevalance of putative haemochromatosis mutations. J Med Genet 1997; 34(4): 275-278.

24. Simsek H, Sumer H, Yilmaz E, Balaban YH, Ozcebe O, Hascelik G, Buyukasık Y, Tatar G.: Frequency of HFE mutations among Turkish blood donors according to transferrin saturation. J Clin Gastroenterol 2004; 38(8): 671-675.

25. Barut G, Balci H, Bozdayi M, Hatemi I, Ozcelik D, Senturk H. Screening for iron oveload in the Turkish population. Dig Dis 2003; 21(3): 279-285. 